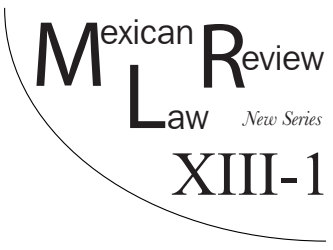

\title{
THE STATE OF EMERGENCY AS AN INSTRUMENT TO OVERCOME ORGANIZED GRIME AND VIGILANTES: A COMPARATIVE STUDY OF MICHOACÁN AND GUERRERO
}

\author{
Felipe Carlos Betancourt Higareda* \\ Enrique Uribe ArZate**
}

\begin{abstract}
In the period of 2009-2014, organized crime subjected all kinds of political authorities and benefited from impunity throughout Mexico, especially in Michoacán and Guerrero. This circumstance provoked a grave constitutional crisis since these authorities were meaningfully overridden and were not able to properly enforce the rule of law in these regions. These phenomena brought about the rise of self-defense groups from local civil societies, as a desperate measure to protect their most fundamental rights from ruthless crime. However, this uprising deepened the constitutional crisis, already experienced in these regions due to the calamitous activities of criminal organisations, because it implied the complete absence of the Mexican state to restore legal order. The present article argues that a formal declaration of emergency by the Mexican President, with the official approval of the Mexican Congress, would have solved efficiently the constitutional crisis that Michoacan, Guerrero and other regions were going through in this period, and would have competently discouraged the expectations of the local people to relay on vigilantes as their last resort to guarantee their fundamental rights in the face of organized crime. This argument is based on archive research, testimonies of people uploaded in video documentaries, the Mexican Constitution, the International Human Rights Law, the doctrine of constitutional dictatorship of Clinton Rossiter, and the legal doctrine on balance and deliberation of Robert Alexy.
\end{abstract}

KEYWORDS: State of emergency, organized crime, vigilantes, Mexico, comparative study.

* Associate Professor at The Faculty of Law of Universidad Autónoma del Estado de México, Ciudad Universitaria S/N, Toluca, México, C.P. 50100.Email:fcbetancourt@uaemex.mx.

** Associate Professor at The Faculty of Law of Universidad Autónoma del Estado de México, Ciudad Universitaria S/N, Toluca, México, C.P. 50100.Email: euribea@uaemex.mx. 
Esta revista forma parte del acervo de la Biblioteca Jurídica Virtual del Instituto de Investigaciones Jurídicas de la UNAM

RESUMEN: En el período de 2009 a 2014, el crimen organizado sometió a toda clase de autoridades políticas, y gozó de impunidad a lo largo y ancho de México, pero especialmente en Michoacán y Guerrero. Esta circunstancia ocasionó una seria crisis constitucional, ya que dichas autoridades habian sido sustancialmente anuladas y no podían hacer valer el Estado de Derecho en su respectivo ámbito de competencia. Esta realidad ocasionó el alzamiento de grupos de autodefensa ciudadana, a lo largo y ancho del país, ya que constituyó una medida desesperada de la sociedad civil para proteger sus derechos fundamentales, frente a la crueldad del crimen organizado. Sin embargo, este alzamiento agravó la crisis constitucional que ya estaban experimentando estas regiones geográficas, ya que evidenció la ausencia completa del Estado Mexicano para hacer valer el Estado de Derecho. El presente artículo argumenta que una declaración formal del Estado de Excepción, realizada por el presidente de la República y aprobada por el Congreso de la Unión, hubiera resuelto eficientemente la crisis constitucional que atravesaban estas regiones geográficas, y hubiera desalentado la formación de estos grupos de autodefensa ciudadana. Este argumento se fundamenta en una investigación con archivos y testimonios documentados en video, así como en la Constitución Política de los Estados Unidos Mexicanos, el Derecho Internacional de los Derechos Humanos, en la doctrina de Clinton Rossiter sobre la Dictadura Constitucional, en la de Evan F. Criddle y Evan Fox-Decent sobre el Estado Fiduciario, y en la doctrina de Robert Alexy sobre la ponderación de derechos fundamentales.

Palabras clave: Estado de excepción, crimen organizado, autodefensas, México, estudio comparado.

\section{Table of Contents}

I. INTRODUCTION

1. Legal Instruments that Control the State of Emergency in Mexico

2. The Doctrine on Constitutional Dictatorship and the State of Emergency.....

II. Research Methods ..................................................................... 39

1. Empirical Dimension ........................................................ 39

2. Legal Dimension.................................................................. 41

III. The Gase of Michoacán ............................................................ 41

IV. The Gase of Guerrero........................................................... 49

V. Отнек Gases ............................................................................. 53

VI. Analysis of the Legal Feasibility of a Declaration of State of Emergency in Mexico 
VII. Proposing Typologies of Emergency and Vigilantes in MeXico

VIII. The Gurrent Debate on the State of Emergency in Michoacán, Guerrero and other Troubled Regions IN MeXico

IX. Final Gonsiderations.

\section{INTRODUCTION}

The academic literature on the state of emergency is vast, since this is an issue that has been researched by political theorists, political scientists and legal scholars alike, especially since the terrorist attacks on the Twin Towers in New York in 2001. ${ }^{1}$ Part of this academic literature deals with the conditions, imposed by the respective Constitutional Law and the International Human Rights Law (IHRL), which a declaration of state of emergency should formally fulfil in order to be considered valid. ${ }^{2}$

Conversely, other literature has focused on thoroughly understanding the principles that a declaration of state of emergency should respect in order to properly reconcile individual rights with community interests. ${ }^{3}$ On the other side, other authors have developed insightful theories on human rights in order to better explain the proper goals, scope and limits, which a state of emergency should hold, so that the relative state can guarantee effectively a 'secure and equal freedom' for the people. ${ }^{4}$

There are even other scholars who, based on comparative law, have proposed typologies of emergency powers classifying coherently the strategies in order to restore constitutional order, with the least human rights violations possible. ${ }^{5}$

Nevertheless, the common ground of the academic literature on the state of emergency is that scholarly works increasingly enrich the criteria to better distinguish an exceptional state of affairs from an ordinary one: No matter

1 Consider, for example, Bruce Ackerman's work: The Emergency Constitution, 121 YaLE L. REP., 1029, 1091 (2004).

2 See Clinton Rossiter, Constitutional Dictatorship, Grisis Government in the Modern Democracies (Routledge 2017) (1948). This scholar even advanced a systematized doctrine on the subject, which will be presented subsequently in this research article.

3 For example, Christop Schreur's work, Derogation of Human Rights in Situations of Public Emergency: The Experience of the European Convention of Human Rights, 9 YALE J. W. Pub. ORd. 113 (1982).

4 For example, Evan J. Criddle \& Evan Fox-Decent, Human Rights, Emergencies and the Rule of Law, 34 Hum. R. QuA. 39 (2012). Their conceptual framework will be described in more detail some pages ahead.

5 See John Ferejohn et al., The Law of Exception: A Typology of Emergency Powers, 2 (2) InT. Const. L. 210, 239 (2004). 
how serious this latter might seem, it must meet a specific benchmark to be deemed a public emergency. ${ }^{6}$

With this academic background, if we were based on the motto that a true state entails the satisfactory performance of all its institutions, as well as the substantive accomplishment of their aims, we would question whether these conditions were or not actually present in specific regions of Mexico, in the period of 2009-2014, and we would also doubt that the constitutional rule of law was indeed enforced then, throughout the Mexican territory.

This inquiry stems from the fact that, in this period, organized crime increasingly committed unlawful actions against the very same Mexican state, which were aimed at weakening it as much as possible to subdue it and prevent the constitutional enforcement of the rule of law, thus leading, step by step, specific regions of Mexico to a de facto state of emergency.

Still, how could we understand a state of emergency? It could be understood as that situation in which the (constitutional) rule of law is not appropriate, solid or powerful enough to solve a circumstance that threatens the viability of the state. This state of affairs could result from a natural disaster, state of war, internal revolt or any other circumstance that excels the standard power of the state to be solved through ordinary means. ${ }^{7}$

\section{Legal Instruments that Control the State of Emergency in Mexico}

At the national level in Mexico, the declaration of state of emergency is specifically regulated by the Article 29 of the Mexican Constitution, which establishes an explicit procedure for this declaration to be validly made. In this procedure, a plurality of authorities participate, ${ }^{8}$ with the goal of keeping in check this extraordinary power that is granted, in the first place, to the Mexican President. This declaration could include two kinds of actions to surmount the specific emergency: a) the suspension of constitutional guarantees, and b) the enactment of special laws to overcome it.

Nevertheless, this declaration could be challenged through a constitutional trial (Fuicio Constitucional), and the derived judicial review would permit the Supreme Court of Justice of the Nation (SCJN, Suprema Corte de Fusticia de la Nación) to reflect on both the procedural and the substantial aspects of the

6 For example, Stephen Humphreys, Legalizing Lawlessness: on Giorgio Agamben's State of Exception, 17 (3) Eur. J. INT. L. 677 (2006), develops and explains thoroughly the different schools of thought on this subject.

7 See David Dyzenhous, Schmitt vs. Dicey: Are States of Emergency Inside or Outside the Legal Order, 27 Card. L. Rev. 2005, 2007 (2005).

8 The President cannot declare the state of emergency without the explicit approval of the Mexican Congress or of the Permanent Commission of this Congress. Conversely, the Mexican Supreme Court of Justice (SCJN) authorizes the decrees enacted during the emergency period, once this Court reviews their conformity to the Mexican Constitution. 
suspension of constitutional guarantees, so that it fully adheres to what is commanded by the Mexican Constitution.

On the other hand, the International Covenant on Civil and Political Rights (ICCPR) has established several restrictions to any state that intends to suspend constitutional guarantees and enact emergency laws to overcome a distress situation. These restrictions are mainly aimed at protecting the human rights and at impeding the abuse of any state when dealing with an emergency. ${ }^{9}$

Additionally, the American Convention on Human Rights (ACHR) explicitly forbids that some constitutional guarantees could be suspended, no matter the seriousness of the emergency that a state confronts. ${ }^{10}$ Furthermore, the formal declaration of a state of emergency should comply with the following requirements to become valid: a) competent subject, ${ }^{11}$ b) valid cause, ${ }^{12}$ c) object, ${ }^{13} d$ ) proper notice, ${ }^{14}$ and $e$ ) conduct. ${ }^{15}$

9 See Claudio Grossman, A Framework for the Examination of States of Emergency under the American Convention on Human Rights, 43 Am. Univ. Int. L. Rev. 1, (1986).

10 The rights that cannot be suspended, in accordance with the ACHR, are the following: a) the right to a legal personality, $b$ ) the right to life, $c$ ) the right to personal integrity, $d$ ) the right of not being slave, $e$ ) the right to the legality and retroactivity of the Law applied, $f$ ) the right to freedom of conscience and religion, $g$ ) the right to a family, $h$ ) the right to a name, $i$ ) the right to nationality, j) the rights of children, and $k$ ) political rights.

11 See Claudio Grossman, A Framework for the Examination of States of Emergency under the American Convention on Human Rights, 43 Am. UnIv. Int. L. Rev. 40, (1986): Competent subject means "the legal person or entity that possess the juridical capacity to declare the state of emergency," in the case of Mexico, only the President of the Republic with the approval of the Federal Congress, and the Supreme Court of Justice, can declare this state of emergency, partially or in the whole territory.

12 Valid cause is referred to those facts that "compel the subject to derogate temporarily from certain of its peace time human rights obligations". According to the ACHR, a valid cause for the declaration of emergency should meet three basic requirements: a) The cause should be based on a real or imminent event, b) The declared situation of emergency should be of exceptional gravity, $c$ ) the emergency should impact the continued viability of the organized community. Claudio Grossman, A Framework for the Examination of States of Emergency Under the American Convention on Human Rights, 43 Am. UnIv. Int. L. Rev. 41, (1986).

13 Object means the "State's obligation to fully protect and promote each of the rights guaranteed by the Convention" in this case, the ACHR. Claudio Grossman, A Framework for the Examination of States of Emergency under the American Convention on Human Rights, 43 Am. UNIV. INT. L. REV. 41, (1986).

14 Proper notice signifies that the "emergency provisions must provide the country's inhabitants a reasonable guide for conduct... and be published in sufficient detail". This proper notice should also a) "explicitly designate those rights guaranteed by the Convention" that would be suspended, b) describe the "circumstances that require the suspension" of specific human rights, and $c$ ) establish "the exact date for the termination of such suspension". Claudio Grossman, A Framework for the Examination of States of Emergency under the American Convention on Human Rights, 43 Am. Univ. InT. L. Rev. 47, 48, (1986).

15 This requirement implies that any state is necessarily limited in the suppression of hu- 
On top of these requirements, there are more derived from the ACHR, which control the suspension of human rights during an emergency: a) necessity, ${ }^{16}$ b) temporality, ${ }^{17}$ c) proportionality, ${ }^{18}$ d) non-discrimination, ${ }^{19}$ e) compatibility with other international obligations,${ }^{20}$ and f) adherence to domestic law. ${ }^{21}$

As it was stated above, these restrictions established by different instruments of the International Human Rights Law are aimed mainly at preventing any state from misusing emergency powers. This goal could be understandable in the case of Mexico, since, given the current weakness of its rule of law, a suspension of human rights could be implemented to achieve other policy aims, instead of seeking to overcome the relative public emergency. ${ }^{22}$

On the other hand, these international legal instruments can enhance the "ex post" controls of a formal declaration of state of emergency in our coun-

man rights, and that it is obliged to prevent possible abuses, and guarantee investigation and punishment of authorities responsible for the violation of human rights, during the period of emergency. Claudio Grossman, A Framework for the Examination of States of Emergency under the American Convention on Human Rights, 43 Am. Univ. Int. L. Rev. 48, 49, (1986).

16 Necessity involves that there must be a serious "assessment of the actual need for each individual derogation of rights", by the respective state, to overcome the emergency and restore the constitutional order. Claudio Grossman, A Framework for the Examination of States of Emergency under the American Convention on Human Rights, 43 Am. UnIv. Int. L. Rev. 51, (1986).

17 Temporality connotes that the suspension of human rights should take place "for the time strictly required by the exigencies of the situation." Claudio Grossman, A Framework for the Examination of States of Emergency under the American Convention on Human Rights, 43 Aм. UNIV. INT. L. Rev. 51 (1986).

18 Proportionality means that the suspension of human rights should be carried out "to the extent... strictly required" to overcome the emergency and restore the constitutional order. Claudio Grossman, A Framework for the Examination of States of Emergency under the American Convention on Human Rights, 43 Am. Univ. Int. L. Rev. 52 (1986).

19 Non-discrimination implies that the suspension of human rights should exclude "any form of discriminatory treatment based on race, religion, sex, ethnic group, political belief or other quality". Claudio Grossman, A Framework for the Examination of States of Emergency under the American Convention on Human Rights, 43 Aм. Univ. Int. L. Rev. 52 (1986).

20 Compatible with other international obligations signifies that any state should review if the suspension of specific human rights does not oppose previous international commitments undertaken by such state. Claudio Grossman, A Framework for the Examination of States of Emergency under the American Convention on Human Rights, 43 Am. Univ. Int. L. Rev. 52, 53 (1986).

21 Finally, adherence to domestic law indicates that the suspension of human rights should also be coherent with the Constitutional normativity enforced by the respective state. Claudio Grossman, A Framework for the Examination of States of Emergency under the American Convention on Human Rights, 43 Am. Univ. Int. L. Rev. 53 (1986).

22 For example, Christop Schreur, Derogation of Human Rights in Situations of Public Emergency: The Experience of the European Convention of Human Rights, 9, Yale J. W. Pub. Ord. 113 (1982) argues that this is the most dangerous use that could be made of a formal declaration of state of emergency and derogation of non-peremptory human rights norms, by any constitutional state. 
try, so that the Mexican state might become more answerable to the international community of its right use or misuse. ${ }^{23}$

\section{The Doctrine on Constitutional Dictatorship and the State of Emergency}

Nonetheless, the doctrine on constitutional dictatorship advanced by Clinton Rossiter has established eleven necessary conditions so that a declaration of state of emergency fulfils its aim of preserving the constitutional order. ${ }^{24}$ These eleven conditions are also aimed at impeding the abuse of emergency powers, by any constitutional dictator, who may use them to boost a longterm authoritarian regime, by means of the very same distress that his own country could be enduring.

23 See Richard B. Lilich, The Paris Minimum Standards of Human Rights Norms in a State of Emergency, 79 (4), Am. J. Const. L. 1074 (1985). This legal scholar affirmed that "at the regional or international level, every declaration of emergency by a state party to a regional or international human rights treaty shall be subject to such judicial or other review as the terms of the particular may provide; while, at the national level, such power of review shall be exercised in terms of the constitution and legal tradition of the concerned".

24 These eleven conditions are the following:

a) "No general regime or particular institution of constituted dictatorship should be initiated unless it is necessary to the preservation of the state and its constitutional order.

b) The decision to institute a constitutional dictatorship should never be in the hands of the men who will constitute the dictator.

c) No government should initiate a constitutional dictatorship without making specific provisions for its termination.

d) All uses of emergency powers and all readjustments in the organization of the government should be effected in pursuit of constitutional or legal requirements.

e) No dictatorial institution should be adopted, no right invaded, no regular procedure altered any more than is absolutely necessary for the conquest of the particular crisis. Certain it is that normal institutions ought to be declared unsuited to crisis conditions unless the unsuitability be painfully evident.

f) The measures adopted in the prosecution of a constitutional dictatorship should never be permanent in character or effect. Emergency powers are strictly conditioned by the purpose and this purpose is the restoration of normal conditions. The actions directed to this end should therefore be provisional.

g) The dictatorship should be carried on by persons representative of every part of the citizenry interested in the defense of the existing constitutional order.

h) Ultimate responsibility should be maintained for every action taken under constitutional dictatorship.

i) The decision to terminate a constitutional dictatorship should never be in the hands of the men who constitute the dictator.

j) No constitutional dictatorship should extend beyond the termination of the crisis for which it was instituted.

k) The termination of the crisis must be followed by as complete a return as possible to the political and governmental conditions existing prior to the initiation of the constitutional dictatorship". Clinton Rossiter, Constitutional Dictatorship, Grisis Government in the Modern Democracies XII-XIV (Routledge 2017) (1948). 
Based on this conceptual framework, it is possible to argue that, at some point, in the period of 2009-2014, some constitutional guarantees could have been suspended, so that the Mexican state would have worked out more energetically the distress that different regions were suffering due to the calamitous activity of organized crime.

The reality was that the constitutional rule of law in Mexico had been debilitated by organized crime, to such a degree, that it had become incapable of preserving the human rights of millions of people. In fact, the infringements to fundamental rights, carried out by organized crime across this country and in this period, were far more serious than any damage that Germany, Italy and Japan had brought about to this sovereign state during the Second World War, when Mexico declared its first state of emergency after the Mexican Revolution.

Nevertheless, Clinton Rossiter's doctrine on Constitutional Dictatorship is not the only conceptual framework that can support the convenience of a derogation of non-peremptory human rights norms, in those regions of Mexico where organized crime has caused calamities.

Another relevant normative theory on this subject is the legal doctrine that regards the state as fiduciary of the duty of protecting its people's basic rights. Based on this established position, the main duty of a sovereign state is to preserve, on behalf of all its subjects, "secure and equal freedom for all", whatever the means might be necessary for this end goal. ${ }^{25}$

Consequently, in accordance with this conceptual framework, emergency powers should be esteemed as the last resort of a sovereign state in order to fulfill this mission, which entails not only the achievement of "secure and equal freedom for all", but also the guaranty of enjoyment of all human rights. ${ }^{26}$

Moreover, based on this insightful theoretical perspective, the formal suspension of non-peremptory human rights during a public emergency may not only be a legitimate faculty of a sovereign state, but also its grave duty so that the human security of all its citizens may be completely assured. ${ }^{27}$

25 See Evan J. Criddle \& Evan Fox-Decent, Human Rights, Emergencies and The Rule of Law, 34 Hum. R. QUART. 42 (2012). To reinforce this argument, both scholars affirm that "under the fiduciary model, states would be permitted to derogate from their human rights obligations where necessary to address regional instability that threatened the state's capacity to maintain legal order".

26 See Evan J. Criddle \& Evan Fox-Decent, Human Rights, Emergencies and The Rule of Law, 34 Hum. R. Quart. 54 (2012). Moreover, these authors argue that "all public powers are constrained and constituted by the state's fiduciary duty to respect, protect and fulfill human rights".

27 See Evan J. Criddle \& Evan Fox-Decent, Human Rights, Emergencies and The Rule of Law, 34 Hum. R. QuART. 60 (2012). One of the ways these scholars framed this argument was: "under the fiduciary theory, a state may not declare an emergency unless exigent circumstances frustrate the state's ability to provide secure and equal freedom through reliance on the laws, practices, or procedures that apply outside an emergency". 


\section{Research Methods}

Since the main argument of the present article is that from 2009 to 2014 Michoacán, Guerrero and other regions of Mexico went through such a constitutional crisis that a formal declaration of emergency would have been completely justified, we will proceed to describe its research methodology in order to test and prove this argument.

\section{Empirical Dimension}

The empirical dimension of this inquiry was researched mainly through qualitative methodology, i.e. case study research based on journalistic archives and testimonies uploaded in video documentaries. Conversely, official quantitative data were used to describe thoroughly the social and economic context of Michoacán and Guerrero, in the period of study.

Notwithstanding, the Mexican official legal concept of emergency was approached from a set theoretical point of view, ${ }^{28}$ which implied that each of its attributes constituted a sufficient condition for the acknowledgement of an emergency.

Based on the Article 29 of the Mexican Constitution, in this legal concept in the period of 2009 to 2014 three attributes (or sufficient conditions, from an established theoretical perspective) would have been necessary in Michoacán, Guerrero and other entities, for an emergency to have been validly recognized: a) serious detriment to public peace, b) pressing threat, and c) dangerous conflict. ${ }^{29}$

A serious detriment to public peace could be defined as that situation in which people cannot perform their ordinary activities, do not benefit from human development, and are constrained in their exercise of civil and political liberties due to social strife. ${ }^{30}$ Thus the main features of this condition could be summarized in the following terms: $a$ ) abnormality, $b$ ) deterioration of human development, and c) constraint in the practice of liberties.

On the other hand, a pressing threat (grave peligro), could be defined as that circumstance in which fundamental rights are constantly menaced by an extraordinary incident, and this threat can put in serious jeopardy these rights,

28 "This is because membership in the concept is determined not just by the choice of attributes and indicators, but also by the role defined for each attribute or indicator (necessary/sufficient)". John Gerring, Social Science Methodology. A Unified Framework 165 (Cambridge University Press 2014).

29 These terms were translated directly from the official text of the Article 29 of the Mexican Constitution: a) Perturbación grave de la paz pública, b) grave peligro and c) grave conflicto.

30 This, and the following definitions of the specific attributes of the legal concept of emergency in Mexico, are elaborated by the authors of this article, since their meaning has not been clarified completely by an official legal interpretation. 
in case of being too lengthy; thus the elements of this attribute could be summarized in the following terms: a) threat in strict sense, b) fundamental rights, and c) the unsustainability of the predicament.

Finally, a dangerous conflict (grave conflicto) could be defined as that context in which people are so polarized by their own interests that the law of violence prevails. Thus, the components of this sufficient condition could be summarized as follows: a) polarization, b) extreme individualism, and c) violence.

As it can be noticed, the methodological challenge in this article consisted in defining consistently each of the attributes contained in the legal concept of emergency, and find primary data that could operationalize them, so that one could be able to validly and reliably describe the degree of distress experienced in Michoacán, Guerrero, and other regions of Mexico, in the period of 2009 to 2014.

The main goal of the empirical inquiry of this article is to test a descriptive argument on the social context of Michoacán, Guerrero and other regions of Mexico, the primary data, chosen for this purpose, will, first and foremost, serve to describe with detail the situation that each case study underwent, and measure the distress that Michoacán, Guerrero and other regions in Mexico endured throughout the period studied.

Specially relevant in this research were the data that could inform us about two crucial manifestations of the constitutional crisis suffered in Michoacán, Guerrero and other regions, which had been caused by organized crime: a) the degree of subjection of authorities and common people to organized crime and $b$ ) the degree of replacement of the constitutional judicial system, by a "civic" one, in order to overcome this crime.

However, the empirical dimension of the present research was not exhausted with describing the emergency that Michoacán, Guerrero and other regions of Mexico faced throughout the period of 2009-2014, but it also included the task of describing the main features of their corresponding vigilante groups.

For this purpose, in the present research synthetic arguments will be used to classify self-defense groups in Michoacán, Guerrero and other regions, consistent with their observed peculiarities through primary data qualitatively analysed, and then a simple typology of these groups will be proposed based on their observed features.

Furthermore, to deeply understand the social and economic context of Michoacán and Guerrero in the period of study, this article correlates the presence of organized crime with other social variables in these states, such as their extent of social scarcities and their degree of schooling backwardness.

The population under study in this research was constituted by all the vigilante groups that appeared from 2009 to 2014 in Mexico, the sample was formed by the vigilante forces of Michoacán, Guerrero and other regions that rose in that period, and the units of analysis were the specific vigilante 
groups that displayed cohesive strategies in the specific regions of study. Finally, the observations on these vigilante groups were carried out through journalistic archives and testimonies uploaded in video documentaries.

Conversely, the journalistic articles and the testimonies uploaded in video documentaries were analysed qualitatively, through descriptive, magnitude, structural, values, evaluation, and versus coding. ${ }^{31}$ These types of coding procedures allowed the authors to possess a more objective system to interpret the degree of social distress endured in Michoacán, Guerrero and other regions of Mexico, in the period of 2009 to 2014.

First and foremost, descriptive coding granted us the opportunity to identify the types of serious crimes that common people reported having suffered from organized crime. Secondly, magnitude coding allowed us, by assigning an alphanumeric character to the descriptive code previously allocated, to recognize the intensity of these crimes.

On the other hand, structural coding was carried out to describe people's interpretation of the gravity of the situation they were suffering, through the response of the following questions: a) Do they think that it is important to replace the constitutional judicial system to promote and defend their fundamental rights? b) Do they think that there is no other way left for them than self-defense, to protect their fundamental rights from organized crime? c) Do they think that the Mexican constitutional rule of law does not preserve sufficiently their basic human rights?

On the other hand, through values coding it was possible to interpret the value system that vigilantes possessed when they rose against organized crime. Finally, versus coding permitted us to elucidate if people approached their own fight against organized crime as a ruthless war.

\section{Legal Dimension}

In terms of the legal methods applied, the authors basically intended to interpret its cases studies in accordance with the legal criteria established in Article 29 of the Mexican Constitution, in the legal doctrines on constitutional dictatorship, and balance and deliberation, and in the relevant instruments of the IHRL, in order to discern if a suspension of constitutional guarantees and the enactment of emergency laws could have been done validly in these cases.

\section{The Gase of MichoacÁN}

At the beginning of the period of 2009-2014, self-defense groups rose mainly in the region of Tierra Caliente, in the west and south west of this state, in the

31 See Johnny Saldaña, The Goding Manual for Qualitative Researchers 83, 122 (Sage 2013). 
Esta revista forma parte del acervo de la Biblioteca Jurídica Virtual del Instituto de Investigaciones Jurídicas de la UNAM

municipalities that bordered the Pacific Ocean and the states of Jalisco and Guerrero (see Map 1). ${ }^{32}$

\section{Map 1. Municipalities of Michoacán with Self-Defense Groups (2014)}

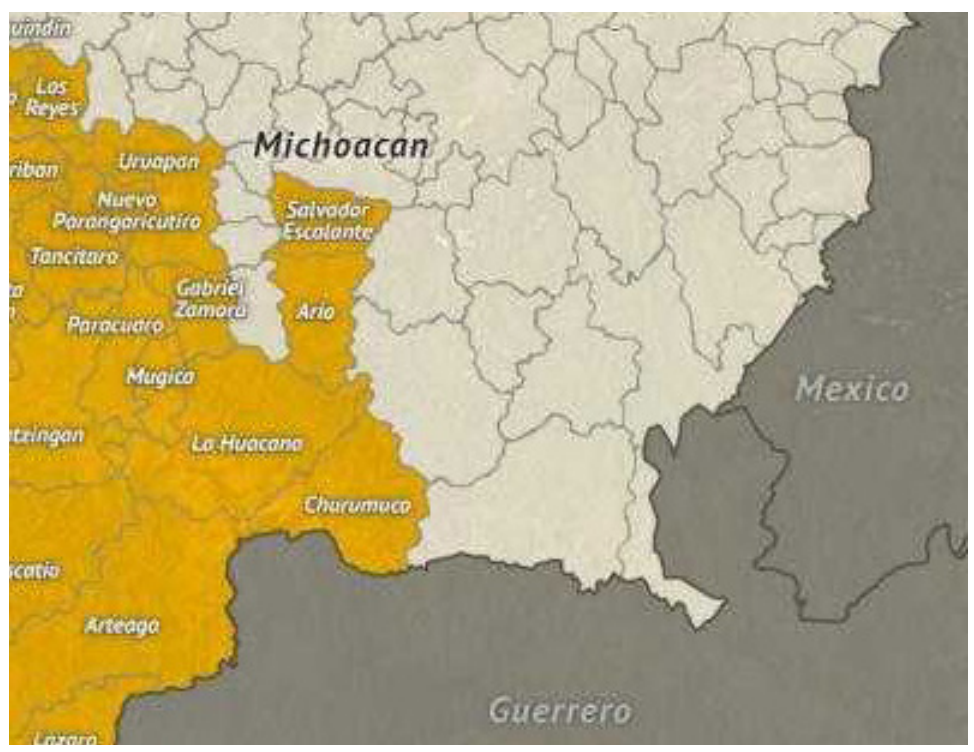

SOURcE: Juan Velediaz. ${ }^{33}$

The main operating criminal organisation in Michoacán, at that time, was the Knights Templar (Caballeros Templarios), which had harassed local communities and seriously damaged the environment. ${ }^{34}$ Indeed, organized crime in the state of Michoacán posed a problem for the sustainable development of this region, since their members had carried out the irrational exploitation of natural resources. This destructive context triggered the formation of vigilante groups across the Tierra Caliente region of Michoacán.

32 These were the main municipalities that witnessed the rise of self-defense groups: Aquila, Coahuayana, Chinicuila, Coalcoman, Aguililla, Apatzingán, Tumbiscatio, Arteaga, Lázaro Cárdenas, La Huacana, Churumuco, Cherán, Tepalcatepec, Buenavista Tomatlán, Parácuaro, Múgica, Tancítaro, Perimba, Cotïa, Tinguindín, Los Reyes, Uruapán, Nuevo Parangaricutiro, Ario de Rosales, Salvador Escalante, Gabriel Zamora.

33 Juan Velediaz, El nuevo mapa de los Autodefensas, Estado Mayor.mx (April 21, 2014), http://wrwestadomayor.mx/41754.

34 See Alberto Torres, Pueblo Purépecha se levanta contra criminales en Cherán, EL UnIversal, 4 May, 2011. People in Cherán were tired of murders, extortions, abductions, forced disappearances, and the deforestation of their land since 2008. 
As a premonition of the formation of these groups, local people started to build barricades to protect their communities from the Knights Templar. ${ }^{35}$ The devastating reality was that this drug-cartel had committed horrendous crimes against common people, ranging from cruel economic extortion to the rape and murder of wives and daughters of members of these vigilante groups. ${ }^{36}$

Unfortunately, the Knights Templar had subjected and paralyzed all kinds of public authorities (executive, judicial and legislative) in the state of Michoacán, by corruption or repression, clearing the path, in this way, to commit the worse possible crimes against common people: Extortions, abductions, rapes, property thefts, murders, psychological terrorism, and more. ${ }^{37}$

On the other hand, the constitutional judicial system could not guarantee a fair trial to the victims of this criminal organisation, because it was so corrupted that the enforcement of the law was manipulated against ordinary people and in favour of criminals. ${ }^{38}$

Furthermore, local people possessed evidence that many policemen and public authorities belonged to the workforce of this criminal organisation, so they could not benefit from any assurance or incentive, whatsoever, to collaborate with these authorities to prosecute and judge its members. ${ }^{39}$

The worst was that organized crime had replaced the Mexican state in taxing the chain of the economic activity of Michoacán and had threatened common people with execution, should they not agree to surrender to their extractive requests. ${ }^{40}$

35 At the beginning of April 2011, "local people in Cherán imposed martial law and closed streets with trunks, stones, bonfires and cars. The squads were formed by kids, women and men armed with sticks, stones, tubes and machetes" to protect their community from the intrusion of the Knights Templar. See Alberto Torres, Pueblo Purépecha se levanta contra criminales en Cherán, El Universal, 4 May, 2011.

36 In words of José Manuel Mireles Valverde, leader of vigilante groups in Michoacán, the kidnapping, rapes and murder of wives and daughters were the main factor that triggered the rise of these groups. See Me gusta leer México, Todos somos Autodefensas, de José Manuel Mireles en FIL Guadalajara 2017, Youtube (Dec. 5, 2017), https:/ / wrwereyoutube.com/watch? $=$ =thhHQ2MEPYA.

37 At the very beginning of their rise in Michoacán, vigilante groups used to surrender members of organized crime to prosecutorial authorities, but they eventually became disappointed, because they realised in time that the criminals they had surrendered to these authorities were released shortly afterwards. See Red Noticiero, Caballeros Templarios en Michoacán: Testimonio Autodefensa Ciudadana, Youtube (June 11, 2013), https://wrerr:youtube.com/watch?v $=7 R$ 6zUlX7Q1UG $t=682 s$.

38 See Id.

39 See Red Noticiero, Cártel Falisco Nueva Generación responde a "La Tuta" lider de los Caballeros Templarios, Youtube (May 30, 2013), https://wrerreyoutube.com/watch?v $=0 X U g K R F O 3 e$ Q. For example, in this documentary, the names of several policemen and prosecutorial authorities are mentioned as accomplices of the Knights Templar in Michoacán and Guerrero.

40 See Al Jazeera America, Mexico's Vigilante State-Fault Lines, Youtube (February 22, 2016), https:/ / wrere:youtube.com $/$ watch?v $=m m n M g D E p \_R 0 \Theta t=1011$ s. For example, in this documentary, 
Many people continued being disappeared without a subsequent criminal investigation, after they had refused to pay an extortion fee to the Knights Templar. ${ }^{41}$ Furthermore, there were many testimonies of people who had assured that the battle against this organisation was truly a matter of life or death, and that public authorities had been overwhelmed by this cartel and had not been able to fight it competently. ${ }^{42}$

Thus, clashes between vigilantes and political authorities unavoidably got under way, and they were exacerbated by the deep lack of trust local people had in the constitutional judicial system. Due to these unfortunate dynamics, people in Michoacán gradually took distance from the government, especially because they did not perceive that the Mexican state was doing enough to protect them against organized crime. ${ }^{43}$

On the contrary, federal and state authorities were more concerned on the rise of self-defense groups than on the causes of their emergence, so some news media focused on the official discourse that condemned their appearance more than on the civic discourse of these groups that had accused political authorities of being co-opted by and colluded with organized crime. ${ }^{44}$

Despite of claiming that their movement had been created against organized crime and not against the Mexican state, some print and broadcast news media started to approach vigilantes in Michoacán as dangerous outlaws, rather than a manifestation of the failure of the rule of law in Mexico. ${ }^{45}$

Nonetheless, some analysts approached the formation of these groups as a good opportunity to establish formal collaboration between civil society and state authorities with the aim to conquer organized crime, although the voices

there are personal stories that would normally correspond to a ruthless war between nations, for example, "they took away my ranches, shot my brother and killed eight of my workers".

41 See Jesús Lemus, Tierra sin Dios. Crónica del desgobierno y la guerra en MichoaCÁN 173 (Grijalbo 2015). This author even states that "Municipal authorities were subjected to the orders of the leaders of the «plaza»: If any of them liked a car or a house, or a woman, or a daughter, or the cattle, or the land or the property of any person, he just needed to send a squad to let the original owner know that it was now his property".

42 See, for example, Vanguardia Mx, Michoacán: Por qué surgen las autodefensas, Youtube (January 27, 2014), https://wrweyoutube.com/watch? $2=h C 9-s 2 H \_Z X s$.

43 See Redacción, Surgen 4 grupos de autodefensa en Michoacán, El Universal, March 10, 2013. Despite of their effort to rebuke the presence of vigilante groups in Michoacán, the official print news media in Mexico consistently reported the increasing rise of these groups in this state, due to the same cause: The harrying of the Knights Templar.

44 See Nurit Martínez Carballo, No hay justificación para autodefensa: CNDH, EL UNIVERsaL, January 28, 2013. The Head of the CNDH, Raúl Plascencia, did not acknowledge self-defense against ruthless crime, as a basic human right that the state should preserve.

45 However, prestigious scholars, like Edgardo Buscaglia, sustained publicly that vigilante groups had emerged as consequence of the absence of the state and the weakness of the constitutional rule of law in México. See Doris Gómora, Advierte experto focos rojos por grupos paramilitares, El UnIVERsal, March 11, 2013. 
against the operation of these vigilantes increasingly opposed any form of collaboration with them. ${ }^{46}$

Unfortunately, the ruling party in Michoacán possessed a strong electoral interest in dismissing the presence of vigilante forces, and it spread in the public sphere, as a mechanism to protect its reputation, the view that this state truly lived under the rule of law. ${ }^{47}$ Therefore, not surprisingly, some news media highlighted the disarmament of self-defense groups, in Michoacán, as a great triumph of the Mexican state. ${ }^{48}$

Furthermore, the CNDH (Comision Nacional de Derechos Humanos) and other Human Rights Organisations publicly refuted the human right to self-defense against organized crime, even when this opposition was leaving people vulnerable to serious violations of their human rights. ${ }^{49}$

The public denial that Michoacán was experiencing tax despotism, territorial control and paralegal order in the hands of the Knights Templar, made seem cruel any claim that this state was truly living under the rule of law, especially when this claim came from human rights activists or public authorities who had been aware of what organized crime had been doing in this state.

However, and despite the attempt to reduce the impact of vigilante groups on the reputation of the state government of Michoacán, the PRI faced a state electoral battle in 2015 that eventually resulted in it losing the government of the state. ${ }^{50}$

After generally describing the events that led to the formation of vigilante groups in Michoacán, and after getting to know, in more detail, the distress that they experienced due to the calamitous activities of organized crime in their state, we are in a better position to learn if the hypothesis set up in Article 29 of the Mexican Constitution to suspend constitutional guarantees and declare the state of emergency was actually fulfilled in the period of 2009 to 2014 in this state.

46 Specially the voices, that supported the regime of Peña Nieto, felt awkward by the spread of the news of the failure of the rule of law in these regions. See Marcos Muédano, fustificar la autodefensa es riesgoso: Naranjo, EL Universal, September 12, 2013.

47 Specially the Governor of Michoacán, Fausto Vallejo, was indeed extremely reluctant to publicly acknowledge the legitimacy of vigilantes. See Mariana León, Considera Vallejo a autodefensa tema "mediático", El Universal, March 22, 2013.

48 See Alberto Morales \& Juan Arvizu, Autodefensas no deben sustituir al Estado: Hurtado, EL Universal, April 29, 2014. In this note, there is not an acknowledgement of the profound motive of the rise of vigilantes and of the replacement of the constitutional judicial system: The protection of the most basic human rights from organized crime.

49 See Silvia Otero, CNDH alerta de proliferación de autodefensas en más estados, EL UNIVERSAL, February 6, 2013.

50 Not surprisingly, Silvano Aureoles Conejo (PRD), was elected new governor of Michoacán in 2015, defeating overwhelmingly the PRI in the corresponding state elections. 
Concerning a serious detriment to public peace, we could observe that Michoacán lived through an abnormal situation: Organized crime was controlling more and more the economic activities of common people through extortion, tax fees, kidnapping, exploitation of natural resources, among others, and this escalating control damaged grievously the standards of living in this state. ${ }^{51}$

Regarding a serious threat, its elements were indeed present in Michoacán in the period of 2009 to 2014, because the threat in strict sense was of such a great magnitude, that not only the lives, properties and freedom of common people were at risk because of frightful crimes, but it also became so unbearable that local people got desperate and were forced to form vigilante groups. This desperation of local people could be judged as a clear sign of the insupportable suffering they endured in this period.

Concerning a serious conflict, the extractive activities of organized crime, in this state, triggered such a severe confrontation between local people and criminal organisations, that their differences could only be solved by extremely violent methods: Both, polarisation and violence, could be observed in this case.

On the other hand, the distress in Michoacán was extremely grave and, to a certain extent, uncontrollable, because it was handled with modest social capital and it fought against a very powerful and ruthless criminal organisation.

One distinctive feature of self-defense groups in Michoacán was that they gathered around a strong leader, José Manuel Mireles Valverde, and was not based on a large civic association spread all through the state, as was the case of Guerrero. Apparently, organized crime could recruit young people more readily in mestizo municipalities than in indigenous ones like Cherán. ${ }^{52}$

As a matter of fact, the emergency in Cherán encouraged the enactment of indigenous law to neutralize more capably organized crime and triggered the replacement of the constitutional judicial system by the local indigenous one. Furthermore, customary law has encouraged the self-organisation of people, it has developed social capital and trust, and it has boosted the community spirit and the spread of democratic practices in the decision-making processes of this municipality. ${ }^{53}$

One of the most important peculiarities of the customary law of Cherán is that its principles encourage democratic practices and deals more with the common good of the municipality than with pursuing an orthodox criminal procedure. Moreover, it possesses a different view on the main aims of the penal system, probably because its context requires a different approach to the purpose and meaning of this system so as to achieve order and peace. In

\footnotetext{
51 See Red Noticiero, Caballeros Templarios en Michoacán: Testimonio Autodefensa Ciudadana, 2013.

52 See Redacción, Cherán: 5 años sin crimen ni partidos políticos, MiLenio, September 13, 2016.

53 See Comenta YT, El Ejemplo del Municipio Mexicano de Cherán, Youtube, (August 30, 2018), https: / / wrew.youtube.com/watch?v $=d H w K a o d n I f U$.
} 
few words, the customary law of Cherán deems justice and fairness in a more substantive than procedural way. ${ }^{54}$

On the other hand, although organized crime is a widespread social phenomenon in Mexico, its presence in Michoacán is correlated with extent social scarcities, low schooling, and poor human development.

The following descriptive data obtained from the Coneval (Consejo Nacional de Evaluación de la Politica de Desarrollo Social) of Mexico, can provide us a better picture of the hard social and economic environment that the people in Michoacán lived through in the period of 2009-2014.

Table 1. Social Scarcities in Michoacín (2010-2014)

\begin{tabular}{|l|c|c|c|}
\hline \multicolumn{1}{|c|}{ Indicators } & \multicolumn{3}{c|}{ Percentage } \\
\hline & 2010 & 2012 & 2014 \\
\hline Proverty & & & \\
People in proverty & 54.7 & 54.4 & 59.2 \\
People in moderate poverty & 41.2 & 39.9 & 45.2 \\
People in extreme poverty & 13.5 & 14.4 & 14.0 \\
People vulnerable due to social scarcities & 28.6 & 30.7 & 25.0 \\
People vulnerable due to income & 4.3 & 3.5 & 4.1 \\
Non poor and non-vulnerable people & 12.3 & 11.5 & 11.7 \\
\hline Social Deprivation & & & \\
People with at least one social scarcity & 83.4 & 85.0 & 84.2 \\
People with at least three social scarcities & 40.3 & 36.6 & 35.1 \\
\hline Indicators of Social Scarcity & & & \\
Schooling backwardness & 30.6 & 26.1 & 27.6 \\
Scarcity of access to health services & 38.2 & 28.6 & 26.2 \\
Scarcity of access to social security & 72.2 & 71.6 & 71.3 \\
Scarcity of quality and spacious housing & 22.4 & 21.1 & 15.4 \\
Scarcity of access to basic housing services & 27.2 & 30.4 & 26.6 \\
Scarcity of access to quality diet & 28.8 & 32.2 & 34.7 \\
\hline Welfare & & & \\
People with lower income than threshold of minimum & 21.6 & 24.2 & 24.4 \\
welfare & 59.1 & 57.9 & 63.3 \\
People with lower income than threshold of welfare & & & \\
\hline
\end{tabular}

SOURCE: Coneval. ${ }^{55}$

54 See Susana María Aguilera, Security, Autonomy and Indigenous Justice: The Alternative Security Model of Cherán, Michoacán 108, 111 (2016) (unpublished MA dissertation, San Diego, University of California). Aguilera affirms that Cherán's legal system has adopted the re-education model for those convicted of crime. From her analysis, we can observe that this system is more focused on the reparation of the offence done to the victim and the community than on punishment for the sake of it. Punishment has a clear purpose: To repair and contribute to the good of the victim and the community as a whole.

55 Coneval, Porcentaje, Número de Personas y Carencias Promedio por Indicador de Pobreza. Michoacán, 2010-2016, 2017. 
To begin with, by the end of the period of $2009-201484.2 \%$ of the local population experienced a kind of social scarcity, 14\% of people lived in extreme poverty, $63.3 \%$ of them did not generate the necessary income to support the threshold of welfare set up by Coneval, among many other relevant descriptive data about the degree of poverty, the social shortfalls and the access to basic services in Michoacán. ${ }^{56}$

In fact, almost all the indicators that measured social shortfalls in Michoacán experienced a setback at the end of the period, for example, the schooling backwardness (rezago educativo) performed worse in 2014 than in 2010, ${ }^{57}$ the share of people in poverty augmented considerably in comparison with the beginning of the period, as well as the percentage of people vulnerable due to a social scarcity. ${ }^{58}$

On the other hand, the portion of people earning an income lower than the cost of the basic food basket grew, but not only in Michoacán but all through the country. ${ }^{59}$ Although it is not the aim of this article to explain the spread of organized crime in Michoacán by means of these descriptive data only, they certainly provide us with the big picture of the social and economic environment that facilitated the recruitment of young people for criminal organisations in Michoacán.

Of course, we must also take into account the decay of family and social values in Michoacán, because it also had an impact on the growth of organized crime in this state. In other words, these descriptive data could demonstrate that, in a context of social scarcities and of shortage of ethical values, criminal organisations tend to recruit many young people for their rank and file.

56 Coneval, Porcentaje, Número de Personas y Carencias Promedio por Indicador de Pobreza. Michoacán, 2010-2016, 2017. In this document, Coneval provides a comprehensive description of poverty and social scarcities in Michoacán. Several indicators were used to measure multiple aspects of poverty and access to basic economic and social goods, such as health and social care, housing, food or a threshold of well-being of people in this state, and they were presented comparatively from 2010 to 2016.

57 Coneval, Porcentaje, Número de Personas y Carencias Promedio por Indicador de Pobreza. Michoacán, 2010-2016, 2017. These data only demonstrate that the schooling level is steadily worsening in this state, which will further hinder its human development, and consequently the conquest of poverty and other social scarcities.

58 Coneval, Porcentaje, Número de Personas y Carencias Promedio por Indicador de Pobreza. Michoacán, 2010-2016, 2017. While in 2010 the share of people in poverty was $54.7 \%$, in 2014 the share rose to $59.2 \%$. Moreover, while in 2010 the share of people experiencing a social scarcity was $83.4 \%$, in 2014 the share rose to $84.2 \%$. These data show that, in spite of the official discourse, there has not been any substantial progress in the conquest of poverty in this state.

59 Coneval, Porcentaje, número de personas y carencias promedio por indicador de pobreza. Michoacán, 2010-2016, 2017. While in 2010 this share was $21.6 \%$, in 2014 the share rose to $24.4 \%$. 


\section{The Gase of Guerrero}

In the period of 2009 to 2014, the social and economic context of Guerrero was even worse than in Michoacán, for example, the percentage of people earning an income lower than the threshold of welfare set up by Coneval was higher in Guerrero than in Michoacán. ${ }^{60}$

Table 2. Social Scarcities in Guerrero (2010-2014)

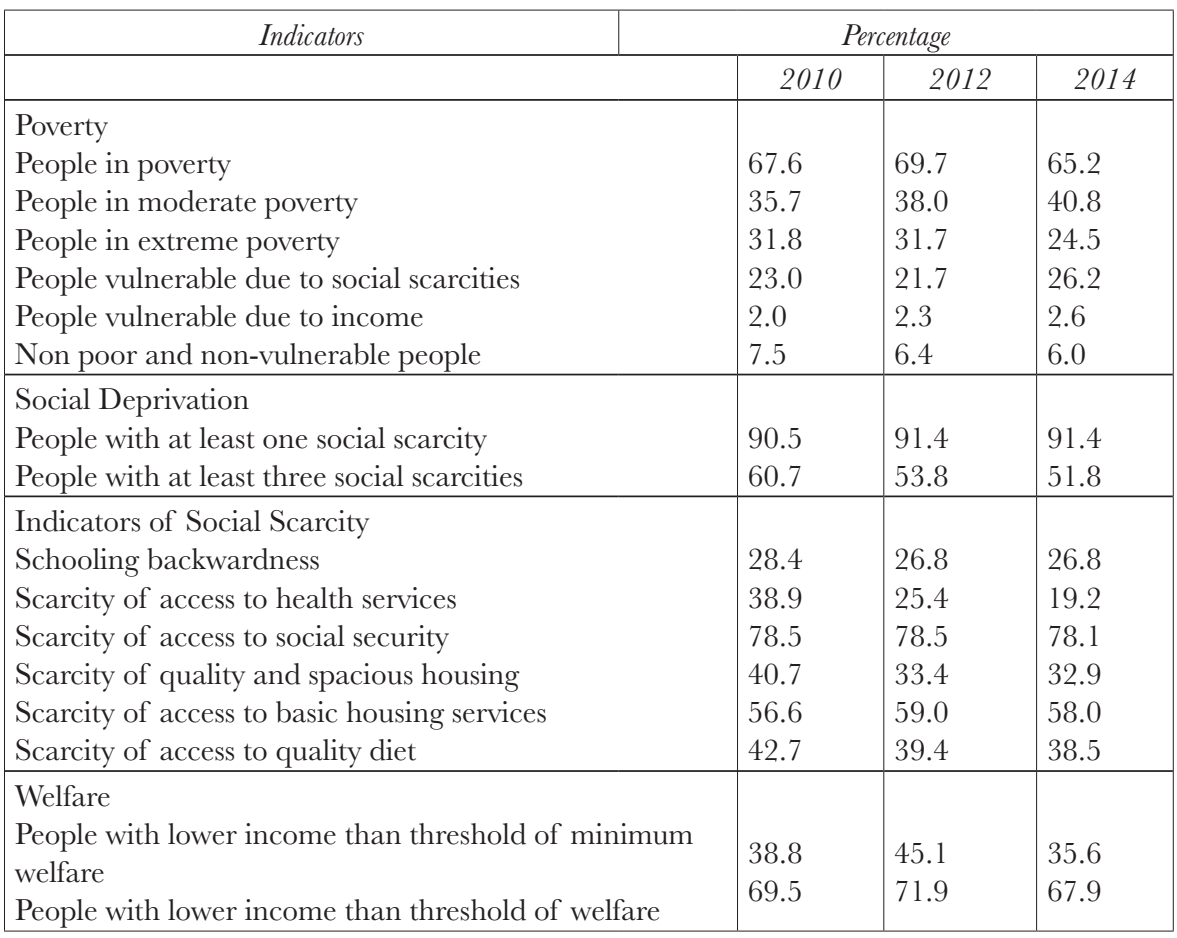

SOURCE: Coneval. ${ }^{61}$

Overall, the indicators used by Coneval to measure social and economic scarcities throughout Mexico performed worse in Guerrero than in Michoacán. ${ }^{62}$ Furthermore, following a national tendency all the other indicators

60 Coneval, Índice de la tendencia laboral de la pobreza. Resultados nacionales y por entidad federativa, 2018. Just as an example, while the share of people earning this kind of income in Guerrero was $65.4 \%$, in the third quarter of 2018, the share in Michoacán was $37.3 \%$ in the same period.

61 Coneval, Porcentaje, número de personas y carencias promedio por indicador de pobreza. Guerrero, 2010-2016, 2017.

$62 I d$. Just as examples, in 2010 the share of people in poverty in Guerrero was $67.6 \%$, while in Michoacán this share was $54.7 \%$, on the other hand, while the share of people in 
of economic and social scarcities suffered a grave reversal at the end of the period of 2010-2015, as can be seen in Table 2 .

According to Coneval, in 2014 the share of people who lived in poverty was $65.2 \%$ and those who lived in extreme poverty formed the $24.5 \%$ of the overall population. ${ }^{63}$ On the other hand, $26.2 \%$ of people in Guerrero were vulnerable due to at least one social scarcity, and $67.9 \%$ of people was earning an income lower than the necessary to buy a basic food basket (canasta básica alimentaria) ${ }^{64}$

However, to make matters worse, the portion of people vulnerable to social scarcities increased from $23.0 \%$ in 2010 to $26.2 \%$ in 2014, and the percentage of vulnerability due to income increased from $2.0 \%$ in 2010 to $2.6 \%$ in 2014, according to these official data. ${ }^{65}$

Finally, the performance of Guerrero regarding the threshold of welfare, was below national average, much worse than in Michoacán, and unfortunately, this threshold is worsening consistently every year. ${ }^{66}$ As it can be observed, there is a strong correlation between extensive social scarcities and the poor human development of Guerrero, with the spread of organized crime across this federative entity.

In addition, Tecoanapa and Ayutla de los Libres were probably the first municipalities where the formation of self-defense groups started in this period. These first vigilantes experienced a paradoxical context though, because while they enjoyed wide popular support, public authorities and some human rights activists condemned their actions from the start. ${ }^{67}$

extreme poverty was $13.5 \%$ in Michoacán, in Guerrero was 31.8\%. There are more examples: While the share of people experiencing scarcity of basic home services in 2010 in Michoacán, was $27.2 \%$, in Guerrero this share was $56.6 \%$. Also, while the share of people experiencing shortage of food in Guerrero in 2010 was $42.7 \%$, this share was 28.8\% in Michoacán.

63 Coneval, Porcentaje, Número de Personas y Carencias Promedio por Indicador de Pobreza. Guerrero, 2010-2016, 2017. The differences between 2010 and 2014 are small. Certainly the share of people living in extreme poverty improved from $31.8 \%$ to $24.5 \%$ in this period, but the share of people living in moderate poverty increased from $35.7 \%$ to $40.8 \%$, and the share of nonpoor and non-vulnerable people decreased $1.5 \%$, from $7.5 \%$ in 2010 to $6.0 \%$ in 2014 .

64 Coneval, Porcentaje, Número de Personas y Carencias Promedio por Indicador de Pobreza. Guerrero, 2010-2016, 2017. These data mean that 2 out of 3 persons cannot buy themselves a basic food supply. This context forces families to multiply their efforts to earn enough income as to sustain a dignifying standard of living, through sending wives and children to work.

65 Coneval, Porcentaje, Número de Personas y Carencias Promedio por Indicador de Pobreza. Guerrero, 2010-2016, 2017. The access to health care remained astonishingly low $(78.5 \%$ in 2010 to $78.1 \%$ in 2014), while the access to basic house services worsened $(56 \%$ in 2010 to $58 \%$ in 2014) in this period.

66 Coneval, Índice de la tendencia laboral de la pobreza. Resultados nacionales y por entidad federativa, 2018. While in Michoacán this share was of $37.3 \%$ in the third quarter of 2018, in Guerrero this share was of $65.4 \%$ in the same period.

67 See Nurit Martínez Carballo, No hay justificación para autodefensa: CNDH, EL Universal, January 28, 2013. 
Another distinctive peculiarity of self-defense forces in Guerrero was that they possessed a visibly stronger social capital than their counterparts in Michoacán. Indeed the UPOEG (Unión de Pueblos Organizados del Estado de Guerrero) coordinated tightly their actions across the state territory, and this civil organisation proved to be quite capable in neutralizing organized crime. ${ }^{68}$ These policias comunitarias detained several people suspected of criminal actions and submitted them to the authorities of the state of Guerrero. ${ }^{69}$

These groups constantly practiced rounds and checkpoints, although they did not have to fight a very powerful and widespread organisation, like the Knights Templar, in Michoacán, but different less powerful criminal gangs distributed across the state. However, local people suffered deeply from extortion practices and the inefficacy of the police and the judicial system against these bands. ${ }^{70}$

In contrast with Michoacán, in Guerrero vigilante groups created, installed and implemented Tribunales Populares to prosecute and judge local criminals, and these events demonstrated how low trust in legal and political institutions fell, within the respective municipalities.

It is obvious that these popular tribunals could not guarantee neither the due process of law nor the constitutional procedural rights of suspected criminal, in order to warrant a fair trial. However, due to the complete failure of the Mexican judicial system in both prosecuting and judging suspected criminals, local people preferred to create, install and put into effect their own popular tribunals. ${ }^{71}$

68 See Juan Cervantes Gómez, Autodefensa guerrerense sigue viva: UPOEG, EL UnIVERsal, February 20, 2013. Bruno Plácido Valerio, the leader of the UPOEG affirmed that their intention was that these self-defense groups would eventually become Policias Comunitarias. The UPOEG, however, held a bitter rivalry with the CRAC-PG (Coordinadora Regional de Autoridades Comunitarias-Policia), another civil association that also coordinated the struggle of other vigilante groups in the region. Despite this rivalry, Guerrero possessed more social capital than Michoacán in the organisation of their self-defense.

69 See Marcos Muédano \& Adriana Covarrubias, Fuerza civil de Ayutla presenta a detenidos, EL UnIVERSAL, February 1, 2013. In January 2013, the UPOEG initiated a popular trial against 54 people captured by the "Policias Comunitarias" of Ayutla and Teconoapa, which was held at the main terrace of the town of El Mesón, within the municipality of Teconoapa. The community authorities even created a file folder for each of the suspected criminals to be judged by the people. Understandably, this event triggered the negative reaction of the $C N D H$ and national authorities against this trial: The Mexican state had been overridden. Eventually, the suspected criminals were submitted to constitutional authorities to be tried and judged properly.

70 See Javier Trujillo, Se disputan Guerrero 18 grupos criminales, Milenio, February 20, 2018. According to the then Secretary of Public Security of Guerrero, Pedro Almazán, out of the eighteen criminal organisations that operated in Guerrero, six worked across the nation and twelve only within the state, these last ones being just local gangs.

71 See Marcos Muédano, Inicia juicio de fuerzas civiles, El UnIVERsal, January 31, 2013. In 31 January 2013, local people in Ayutla de los Libres tried and judged suspected criminals who were accused of kidnapping, extortion, rape and robbery. 
Map 2. Municipalities of Guerrero with Self-Defense Groups (2015)

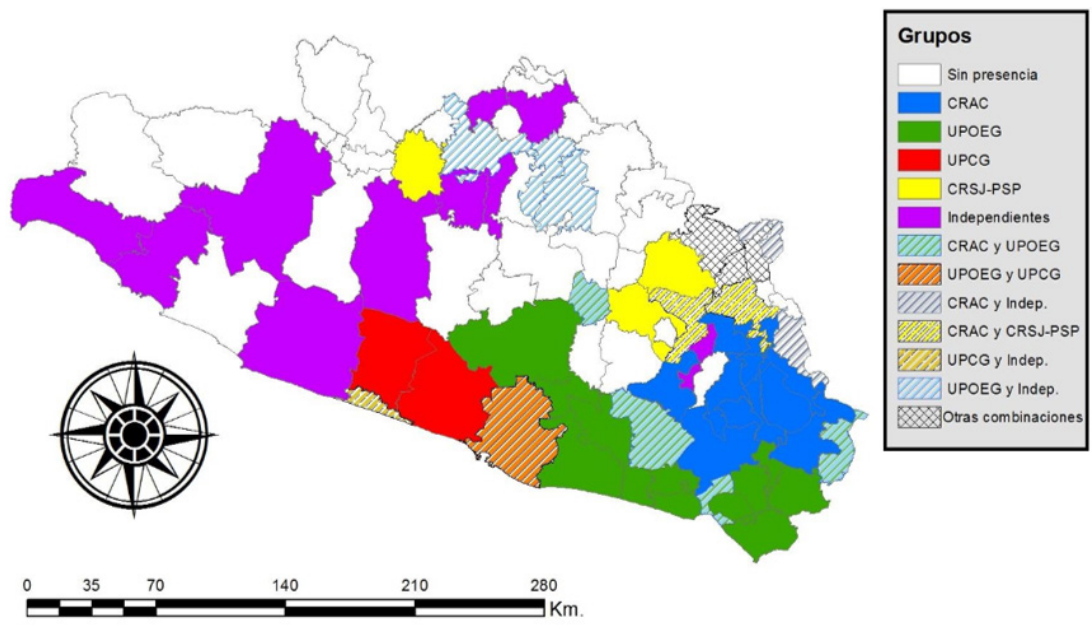

SOURCE: Víctor Manuel Sánchez Valdez. ${ }^{72}$

The implementation of these tribunals provoked the alarm of the CNDH, due to its justified fear that they could arbitrarily suppress fundamental human rights of suspected criminals, by not respecting the due process of law and the constitutional procedural rights of suspected criminals. ${ }^{73}$

Although slightly less severely than in Michoacán, people in Guerrero endured likewise an abnormal situation, as well as the constraint to carry out their ordinary lives, and a serious deterioration of their standards of living, precisely because of the harassment from organized crime. To sum up, attributes of a serious detriment to public peace could be observed.

With respect to a pressing threat, people in Guerrero did suffer threat strictly speaking, because organized crime practiced extortion, kidnapping, rape, murder, theft and other violent crimes, with increasing ruthlessness and cruelty.

Furthermore, their fundamental rights were at high risk due to this devastating activity of organized crime and, ultimately, with regard to the danger

72 In Building Resilient Communities in Mexico: Civic Responses to Crime and ViOLEnce 14 (Woodrow Wilson International Center for Scholars and The University of San Diego, 2015).

73 See Javier Cruz Angulo, Dictaduras Comunitarias, El Universal, January 31, 2013. In this article, the author recalled that there had been grievous precedents of abuse of human rights, by popular tribunals erected by self-defense groups in Guerrero. Angulo claimed that these groups had overridden the Mexican Constitution, and that they had acted above it, behaving arbitrarily (with demagoguery) at imposing sentences to suspected criminals, without sufficient evidences. 
of this risk, perhaps the best indicator of this circumstance was the exasperation of the people and their decision to try and judge, by themselves, suspected criminals through popular trials.

Finally, respecting a dangerous conflict, we can claim that the calamitous activity of organized crime and the absence of the Mexican state triggered a bitter violent conflict between criminals and the vigilantes, to the point of overriding the constitutional judicial system to settle their differences.

Certainly, organized crime in Guerrero was not so solidified across the state as in Michoacán, so although the distress was real, people in Guerrero could neutralize better their threat than their counterparts in Michoacán.

Finally, the most severe symptom of emergency in Guerrero was the de facto replacement of the constitutional judicial system by a customary one in several municipalities across the state. This replacement could have represented a syndrome more of exasperation than of desperation of the people. It could also have been a clear sign of the strength of social capital and of the power of civic organisations against criminal ones across the state. Thus, Guerrero might be considered a good example of how a strong social capital contributes decisively in the struggle against organized crime.

\section{Other CAases}

From Sonora to Yucatán ${ }^{74}$ civil society in Mexico has organized vigilante groups to protect their lives, freedoms, properties and their fundamental rights from crime. In all these cases, people have complaint of the absence of the state facing crime. ${ }^{75}$

By the end of 2013, there were versions that self-defense groups were present in eleven states of Mexico. ${ }^{76}$ However, this number has increased in recent years, and nowadays there are claims that these groups are also present in states that were considered relatively safe, such as Yucatán, Sonora, Quintana Roo or Mexico City. ${ }^{77}$

74 See Eduardo José Cabrera Ruiz, Nuevos Grupos de Autodefensa ... ahora en Tucatán, ExCELsIoR, March 20, 2013. For example, in Yucatán, at the municipality of Kanasín, self-defense groups armed themselves with sticks and machetes to stop robberies and rapes in their neighbourhoods.

75 See Redacción, Ahora en Sonora irrumpe grupo de autodefensa; lo encabeza un ejidatario llamado Francisco Villa, Proceso, February 5, 2014. For example, both in Sonora and Sinaloa, some ejidatarios organized self-defense groups to protect their properties and homes from being burned and robbed, at the same time they accused state authorities of passivity in front of crime.

76 See Grillonautas2, Grupos de Autodefensa presentes en 11 estados del país, Youtube, December 21, 2013, https://werereyoutube.com/watch?v=EVhtdeGIworw. These states were: Michoacán, Guerrero, Oaxaca, Estado de México, Chiapas, Morelos, Veracruz, Puebla, Hidalgo, Tlaxcala and Chihuahua.

77 See Redacción, Empresarios de Quintana Roo crean grupo de autodefensas contra corrupción, ANIMaL Político, June 28, 2017. In Quintana Roo, businessmen unleashed in 2017 a new self-de- 
An interesting case, in the period of 2009 to 2014, was Chihuahua. In this state, people suffered desperation likewise, due to the violence and ruthlessness of organized crime, so they to self-defense, despite of the criticism of Human Rights activists and authorities alike. ${ }^{78}$ On the other hand, another state that has suffered immensely the violence of organized crime is Tamaulipas, to such an extent, that, during many years local people could not exercise civil liberties to associate and meet to plan their self-defense. ${ }^{79}$

Many municipalities in this state lived a de facto subjection to organized crime, which controlled all their ordinary activities and properties. ${ }^{80}$ People literally lived terrorized and with utmost fear, in such a way, that they could not speak publicly about the wrongdoings of organized crime and the sufferings its members were causing them, inasmuch as they were immediately eliminated should they intend to do so. ${ }^{81}$

Nevertheless, by early 2014, the first reports about vigilante groups in this state were published. These groups, like their counterparts in Michoacán, were facing very powerful criminal organisations that had destroyed trust and social capital in Tamaulipas, thus the capacity of people to capably organise their self-defense. That is why the task of overcoming drug cartels was enormously difficult for these new vigilante groups.

fense group against the very same governor of the state, Carlos Joaquín González, who they accused of leading a new drug cartel, which was extorting many businesses in that state. On the other hand, in 2013 there were rumours that the Counties of Tlalpan, Iztapalapa and Xochimilco, in Mexico City, had self-defense forces as well, although the government of Mexico City always denied this fact. See Ilich Valdez, No habrá autodefensas en la ciudad: Mancera, MiLENIO, November 25, 2013.

78 See Redacción, Advierten riesgos por milicias comunitarias, El UnIVERSAL, July 11, 2009. Due to high rates of violent crimes, the government of Chihuahua decided to arm and train civilians, at the community of "Le Baron", to perform police tasks, as a strategy to neutralize organized crime. The state authorities of Chihuahua openly proposed collaboration and coordination with civil society to conquer crime.

79 For example, Ciudad Mier, Tamaulipas, by 2010, became a ghost town, since almost all its population had to emigrate to neighbour towns or even to the United States of America, due to the ruthless death threats of organized crime. See Gustavo Castillo García, Amenazas de muerte de Zetas hacen de Mier, Tamaulipas, pueblo fantasma, LAJornaDA, November 11, 2010; and see Axellmx1, Ejército ingresa a pueblos fantasma de Tamaulipas, YouTube, December 8, 2010, https:// wrow:youtube.com/watch? $=F \mathcal{N}$ IFSR1bb4.

80 The main criminal organisation operating in this state was Los Zetas, perhaps the bloodiest and most ruthless that has ever existed in Mexico. There were other two which intended to defeat Los Zetas in this state, the Sinaloa Cartel and the Gulf Cartel. See Said Rahal, Narcos dejan pueblos fantasmas en Tamaulipas, Youtube, March 2, 2010, https://wrere.youtube.com/ watch? $v=g k X O u 4 K v X p 4$.

81 See Axellmx1, Ejército ingresa a pueblos fantasma de Tamaulipas, 2010. 


\section{Analysis of the Legal Feasibility of a Declaration of State of Emergency in Mexico}

The doctrine explained by Robert Alexy on balance and deliberation of the right to protection (of basic goods) and the right to defense (of liberties), can provide us with a proper criterion to discern the necessity, proportionality and adequacy, of a suspension of constitutional guarantees and of the enactment of emergency laws, so that the constitutional order may be restored completely in specific regions of Mexico.

In consonance with Robert Alexy, ${ }^{82}$ the right to protection (of basic goods) implies the duty of the state to perform a positive action aimed at safeguarding fundamental rights. However, sometimes the necessary action that could protect these basic rights interferes with or harms a particular right to defense (of a liberty). Alexy believes that the fair solution in this hypothetical collision of rights consists in balancing, in accordance with the principle of proportionality, both kinds of rights. ${ }^{83}$

Furthermore, the principle of proportionality is composed of three subprinciples: a) adequacy, b) necessity and c) proportionality in strict sense. Adequacy implies that a constitutional guarantee should not be violated unless its transgression pursues the enhancement of another constitutional right. ${ }^{84}$ In addition, necessity suggests that if the state must choose between two methods of protecting fundamental rights, the one that interferes the least with the right to defense (of liberties) should be chosen. ${ }^{85}$

Lastly, proportionality in strict sense proclaims the principal law of balance and deliberation: "As much as a principle may be harmed, so much important is to guarantee the other one" ${ }^{86}$ Robert Alexy expresses this principle through a mathematical formula:

$$
W_{i, j}=I_{i} / I_{j}
$$

Where $\left(\mathrm{W}_{\mathrm{i}, \mathrm{j}}\right)$ means the weight of principle $\left(\mathrm{P}_{1)}\right.$ in the particular study case, $\left(\mathbf{I}_{\mathrm{i}}\right)$ stands for the damage of $\left(\mathbf{P}_{1}\right)$ by a particular measure $(\mathbf{M})$, and $\left(\mathbf{I}_{\mathbf{j}}\right)$ implies the negative effects of the omission of $(\mathbf{M})$ (and of the omission of the damage to $\left.\left(\mathrm{P}_{1}\right)\right)$, to the principle $\left(\mathrm{P}_{2}\right)$.

In this formula, $\mathrm{P}_{1}$ symbolizes the constitutional right to protection (of basic goods), $\mathrm{P}_{2}$ speaks of the constitutional right to defense (of liberties). ${ }^{87}$

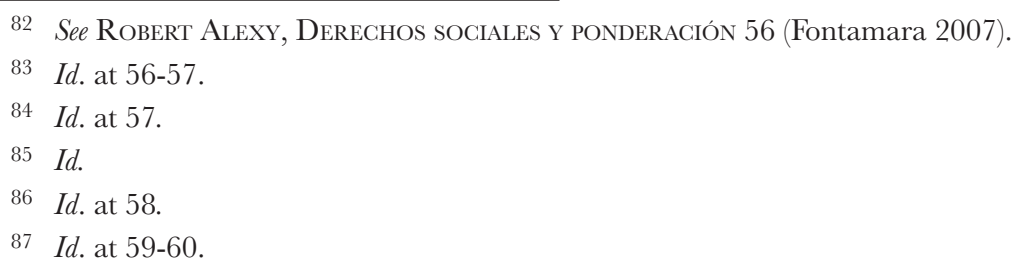


Thus, from the principle of proportionality and its sub-principles, we can draw two interesting conclusions:

A) If the harm to a right to defense (of liberties), caused by implementing a particular measure $(\mathbf{M})$, is greater than the harm to a right to protection (of basic goods), by not adopting this measure (-M), then this measure should not be implemented, for the sake of enhancing constitutional liberties.

B) But, if the harm to a right to protection (of basic goods), caused by not implementing a particular measure $(-\mathbf{M})$, is greater than the harm to a right to defense (of liberties), by adopting this measure (M), then this measure should be implemented, for the sake of preserving fundamental rights. ${ }^{88}$

The argument of this article is that the second conclusion was the case of Michoacán Guerrero and other states of Mexico, in the period of 2009 to 2014, because the suspension of constitutional guarantees and the enactment of emergency laws, would have benefited enormously the right to protection (of lives, properties, physical integrity, fundamental freedoms, etc.) of common people, and would not have harmed intensely their right to defense (of specific civil liberties).

In few words, the rights that needed to be protected by the state (lives, properties, freedoms, physical integrity, etc.) were far more relevant than the rights that needed to be defended from the intrusion of the state (e.g. confidentiality of bank accounts, restriction of movement in certain hours, prohibition of public gatherings).

There must be a comparative value judgment between the enforcement of the rule of law $\left(\mathrm{P}_{1}\right)$ and specific constitutional guarantees of explicit people $\left(\mathrm{P}_{2}\right)$. The Mexican state has the responsibility of securing its viability, even at the cost of not respecting, momentarily, constitutional rights of particular people (e.g. the right to an orthodox criminal procedure or some rights to confidentiality in financial matters).

This means that whenever $\left(\mathbf{P}_{1}\right)$ (the rule of law) is in danger, $\left(\mathbf{P}_{2}\right)$ (orthodox criminal procedure) or $\left(\mathrm{P}_{3}\right)$ (specific civil liberties or particular rights of confidentiality) should be left aside, because $\left(\mathrm{P}_{1}\right)$ protects a far more relevant good for society than $\left(\mathrm{P}_{2}\right)$ or $\left(\mathrm{P}_{3}\right)$. In fact, crimes against the state $\left(\mathrm{P}_{1}\right)$ entail the destruction of all that could make people happy and enjoy their fundamental rights: life, freedoms, property, integrity, human development $\left(\mathrm{P}_{2}, \mathrm{P}_{3}\right.$, etc., etc., that is why the right to a functioning, healthy, capable and strong state $\left(\mathrm{P}_{1}\right)$ prevails over other constitutional rights $\left(\mathrm{P}_{2}, \mathrm{P}_{3}\right.$, etc. $)$, no matter how basic they appear to be.

$88 \quad I d$. at $63-65$. 
Nevertheless, if the state is not enduring a pressing threat to its viability or living through a grave distress, then $\mathrm{P}_{2}, \mathrm{P}_{3}$, etc. (constitutional guarantees) are worth more than any public policy that pretends to strengthen the rule of law $\left(\mathrm{P}_{1}\right)$, but damages at the same time these constitutional rights. This means that, in ordinary and peaceful circumstances, procedural rights of suspected criminals should always be respected. In this case, there would be no excuse to override these rights.

The first source of power of the state is its viability, and once it works, it makes the constitutional rule of law function as well. This implies that, in case of a hazardous threat, some constitutional rights should be overridden to guarantee the existence of the state and the rule of law.

To judge the case of Mexico fairly, based on the doctrine of balance and deliberation of Robert Alexy, it is important to answer the following questions: Would the suspension of constitutional guarantees in Michoacán, Guerrero and other regions, in the period of 2009-2014, have been a competent measure to address efficiently their distress?

Our argument is yes, it was a fitted action, because it would have been at the service of restoring the constitutional order in these regions, thus at the service of protecting fundamental rights of people living there.

The second question is would it have been necessary to suspend constitutional guarantees and enact emergency laws in Michoacán, Guerrero and other regions, in the period of 2009-2014, to capably oppose organized crime? Our answer is yes, it would have been necessary, but the options to subdue competently criminal organisations were wide, and the Mexican government was forced to choose one that would have been efficient and would have damaged as little as possible procedural, civil and political rights of people.

The final question is would the suspension of constitutional guarantees have been proportionated with the distress that Michoacán, Guerrero and other states suffered in the period of 2009 to 2014? Our answer is yes, it would have been proportionated. However, ideally it should have lasted a short period of time, because it would have been quite powerful in re-establishing the rule of law and guaranteeing the protection of human rights.

Conversely, the suspension of constitutional guarantees and the enactment of emergency laws could have helped competently in dismantling rapidly criminal organisations in these regions, and in enhancing the responsiveness of the Mexican state against drug-cartels.

Furthermore, these measures could have improved the intelligence of the Mexican state (strategic and tactical) in order to break down the financial support and supply of arms for drug cartels, through allowing direct access to confidential information from economic transactions related to these criminal activities. ${ }^{89}$

89 See John Bailey, Grimen e impunidad. Las trampas de la seguridad en México 214 , 219 (Random House Mondadori 2014). 
On the other hand, emergency laws could have powerfully worked to improve institutional coordination by avoiding duplicity of functions and unifying protocols to detain suspected criminals. Moreover, the formal declaration of emergency in these regions could have provided space-time for the quality improvement of institutions and physical infrastructure to capably enforce the rule of law. ${ }^{90}$

In addition, emergency laws could have contributed to improve mechanisms of control of authorities and society (judicial, assets, anti-corruption and social), in specific regions of Mexico or throughout the country. ${ }^{91}$ Finally, these laws could have also contributed to achieve a capable law enforcement system, as well as competent prosecutorial and judicial systems, to vigorously strike organized crime, and which could have continued, in substance, after the emergency would have formally ended. ${ }^{92}$

\section{Proposing Typologies of Emergency and Vigilantes in Mexico}

In terms of the severity of the emergency, it can be sustained that Guerrero bore a less intense distress than Michoacán. People in Guerrero could manage to make their suffering more tolerable, by implementing popular tribunals; and this replacement of the constitutional judicial system, by a customary (indigenous) one, plus the scattering of criminal organisations across the state, made people possess a better context to face up to organized crime.

Concerning the strength of self-defense groups, Guerrero's vigilantes could be rated as first class forces, since they had been strongly solidified through widespread civic organisations, whereas the vigilantes in Michoacán can be considered as second class forces, because they had not been unified through widespread social capital, but were only well coordinated around a strong personal leader (José Manuel Mireles Valverde) in order to stand up to the Knights Templar.

On top of that, it could be observed that the forces in Michoacán were more vulnerable to the infiltration of organized crime than in Guerrero. On the other hand, the forces in Guerrero were more cohesive and better coordinated.

The third-class forces, in terms of their strength, were those that had worked dispersedly, without coordination, thus being left with much more difficulties to conquer their common enemy. This could well be the case of self-defense groups in other federative entities, like Tamaulipas, Chihuahua, Sonora, Yucatán and Quintana Roo.

\footnotetext{
90 See Id. at $47,48$.

91 See Edgardo Buscaglia, Vacíos de poder en México. Cómo combatir la delincuenCIA ORGANIZADA 28, 29 (Random House Mondadori 2013).

92 Id. at 179, 200.
} 
Nonetheless, after the analysis of primary data, it is possible to argue that vigilantes in Guerrero put into effect more like a rebellious movement against organized crime, whereas vigilantes in Michoacán implemented more a kind of ruthless war, because their enemy was more difficult to defeat.

However, in both cases we could notice an acknowledgment that the rule of law was not capable of neutralizing solidly organized crime; that is why it was set aside in some municipalities, so that the indigenous customary law could instead rapidly restore peace and order.

\section{ViII. The Gurrent Debate on the State of Emergency in Michoacán, Guerrero and Other Troubled Regions in Mexico}

Some scholars have argued that there are different options to a formal declaration of state of emergency, which do not entail the restriction of nonperemptory human rights and could be equally effective in improving public, interior and national securities in Mexico, particularly in Michoacán and Guerrero. ${ }^{93}$ For example, the implementation of sensible measures of intelligence, strategy and technology in order to capture, subjugate and institute proceedings against members of organized crime. ${ }^{94}$

Nonetheless, Mexican authorities have attempted to implement policies other than a formal declaration of state of emergency, such as the sanction of the Law on Interior Security and the Law on National Security, whose enforcement, incidentally, has implied the acknowledgement of a de facto state of exception in some regions of Mexico, and has authorized military actions that can only be performed in the course of emergency periods. ${ }^{95}$

In contrast, a formal derogation of non-peremptory human rights norms, which is the logical output of a formal declaration of state of emergency, if properly implemented, would not standardize an abnormal situation. On the other hand, the enforcement of these laws could turn a factual state of emergency into an endless state of affairs, by way of authorizing the inter-

93 For example, Carlos Galindo López, et. al., Seguridad interior: elementos para el debate, 39, Tem. Estr. 33, 34 (2017), mention different policies that should be discussed, at the national level, to achieve this goal: a) judicial reform, b) police reform and professionalization, c) the autonomy of prosecutors, among others.

94 See John Bailey, Grimen e impunidad. Las trampas de la seguridad en México 192, 231 (Random House Mondadori 2014). This scholar provides thoughtful and comprehensive policy advices to the Mexican government in order to enhance citizen security and overcome organized crime throughout Mexico.

95 See, for example, Marcos Pablo Moloeznik, El proceso de militarización de la seguridad pública en México (2006-2010), 24 (48) FRON. N. 138, 139 (2012). This scholar argues that if the official judicial interpretation states that Mexico is living peaceful times, then Art. 129 of the Mexican Constitution should be fully enforced: The army should not go out from their proper stations. 
vention of military forces in the prosecution of organized crime in ordinary circumstances. ${ }^{96}$

Additionally, emergency powers can nurture the rapid, decisive and efficient response of Mexican authorities to reestablish public, interior and national securities in Mexico, and hastily restore the constitutional order across this country, once criminal organizations are effectively curbed through these powers. Furthermore, a formal declaration of a state of emergency would force the Mexican state to design and publish, as soon as possible, a detailed plan of action to reinstate effectively the constitutional order and enforce efficiently the rule of law across all those regions struck by organized crime. ${ }^{97}$

Additionally, this kind of declaration would imply the formal acknowledgement of a crisis, thus the need for the Mexican President to exercise extraordinary faculties in order to face such a situation and reestablish constitutional normality. On the other hand, the Law on Interior Security and the Law on National Security point the way to the standardization of the intervention of military forces in the prosecution of organized crime, which could increase the ordinary distress of Mexican society, because of the lack of a specific plan and dateline to bring back constitutional normality. ${ }^{98}$

Nevertheless, it is a reality that the Mexican state faces such serious security challenges that, a transitory derogation of non-peremptory human rights norms, through a formal declaration of state of emergency, may still seem as an insufficient mechanism to competently meet those challenges.

This circumstance could explain why the approval of these laws was so well regarded and welcomed by presidents Fox, Calderón and Peña Nieto, and their followers, in their respective administrations (sexenios), since these laws provided them with practical tools to manage the armed conflict with organized crime, without committing themselves to develop a thorough and detailed plan to restore the constitutional order within a specific dateline, as a formal declaration of state of emergency would have forced them to accomplish. ${ }^{99}$

Because of this situation, the authorization of these laws could have also meant that both the public emergency and the humanitarian crisis brought

96 See Antonio Barreto Rozo et. al, Los costos constitucionales de la guerra contra las drogas: dos estudios de caso de transformaciones de las comunidades politicas 43 ISON. 151, 193 (2015). These scholars claim that once the Law on National Security started to be effective (2005), there was no longer clarity about the specific functions that the army can perform in the fight against organized crime in Mexico.

97 John Ferejohn, et al, The Law of Exception: A Typology of Emergency Powers, 2 (2) InT. Const. L. 217, (2004). Moreover, these authors argue that "once the emergency subsides, there will be a return to ordinary legal and political processes".

98 Laura Medellín Mendoza, El resguardo de la soberanía del Estado constitucional en la lucha contra el crimen organizado en México, 12 (31) Tray. 126, 129 (2010).

99 See Laura Medellín Mendoza, El resguardo de la soberanía del Estado constitucional en la lucha contra el crimen organizado en México, 12 (31) TraY. 126, 129 (2010). 
about in some regions of Mexico by the destructive activities of organized crime, were much worse than initially thought, and they could have symbolized the recognition of the Mexican state of its incapacity to solve these crises through transitory emergency powers.

Moreover, the ugly truth is that, although unacknowledged, some regions of Mexico, like Michoacán and Guerrero, live in a quasi-state of war, since organized crime constantly carries out extremely ruthless strategies to permanently undermine the Mexican state's army, police forces, rule of law and ordinary institutional framework. ${ }^{100}$

Because of this state of affairs, the Mexican legal doctrine needs to update its interpretation of a public emergency, based on the most recent and relevant scholarly contributions, so that rising social hostilities executed by non-state agents and aimed at subjugating state authorities can be faced up properly and successfully, by the Mexican state, without the need to enact controversial laws.

On the other hand, some scholars have asserted that the Mexican state has not observed its constitutional principles at sanctioning the Law on Interior Security and the Law on National Security since, according to them, these laws were not properly based on the Mexican Constitution, and they openly contradicted its Art. 129.101

In contrast, a formal declaration of state of emergency and derogation of non-peremptory human rights norms would avoid this kind of criticism by being duly motivated and justified in Article 29 of this Constitution, since its aim would be to restore the constitutional order harmed by the calamitous activities of organized crime.

Furthermore, a formal state of emergency could stop the process of alteration (or reinterpretation) of the Mexican Constitution, which both the Law on Interior Security and the Law of National Security have prompted in order to justify the ordinary intervention of military forces in the prosecution of criminal organizations. ${ }^{102}$

Moreover, the Law on Interior Security and the Law on National Security might become counterproductive in the long term, because they address the armed conflict against organized crime as if it were an ordinary issue, in which constitutional principles could be entirely complied with. In contrast,

100 Precisely in the third week of October 2019, there were four serious attacks to police and military forces across Mexico: in Michoacán (14/10/2019), Guerrero (15/10/2019), Tamaulipas (16/10/2019), and Sinaloa (17/10/2019).

101 See, for example, Carlos Galindo López et al., Seguridad Interior: Elementos para el debate, 39, Tem. Estr. 12, 24 (2017).

102 See Laura Medellín Mendoza, El resguardo de la soberanía del Estado constitucional en la lucha contra el crimen organizado en México, 12 (31) TRAY., 108 (2010). This scholar has criticized that, in Mexico, the constitutional order has been interpreted in order to justify government decisions, based on certain official goals, but without considering the original intention of the constitution-maker. 
a formal state of emergency would openly acknowledge that these principles could not be fully respected in this commitment, since the institutional disturbance caused by criminal organizations in some regions of Mexico should be deemed as critical or exceptional in nature. ${ }^{103}$

Moreover, through the formal declaration of a state of emergency, in the course of dismantling criminal organizations the state could avoid the weariness of being constantly accused of non-peremptory human rights violations. However, in the long term, this formal declaration could better guarantee the definitive restoration of the rule of law in Mexico, hence the conclusive enforcement of all human rights across all those regions struck by organized crime. ${ }^{104}$

Finally, a formal declaration of state of emergency in Michoacán, Guerrero and other regions of Mexico might stop and repair some of the "constitutional costs" that military forces have produced to the Mexican state while guaranteeing public, interior and national securities across these regions. ${ }^{105}$

\section{Final Considerations}

The fact that the constitutional judicial system could not preserve human rights of victims of organized crime, the reality that fundamental rights were substantially overridden by this crime, and the truth that horrendous abominations were overwhelming in Michoacán, Guerrero and other states, constituted a solid ground for the acknowledgement of a constitutional crisis in these regions.

Furthermore, these circumstances prompted either a serious threat or a dangerous conflict or a grave detriment to public peace (each one being a sufficient condition for the valid suspension of constitutional guarantees) in the regions of study of the present research.

103 See Laura Medellín Mendoza, El resguardo de la soberanía del Estado constitucional en la lucha contra el crimen organizado en México, 12 (31) TRAY. 126, 129 (2010). Medellín regrets that, in practice, these laws pave the way for a de facto state of emergency in Mexico, which is actually a far worse situation than a de jure or formal declaration of state of emergency that the Mexican President could have made.

104 See Evan J. Criddle \& Evan Fox-Decent, Human Rights, Emergencies and The Rule of Law, 34 Hum. R. QuART. 41 (2012). In order to stress this end goal of a formal declaration of state of emergency, these scholars argue that "Non-peremptory human rights norms are subject to derogation in contexts where the strict observance of these norms would conflict with the state's overarching fiduciary obligation to guarantee subjects' secure and equal freedom.”

105 See Antonio Barreto Rozo et al., Los costos constitucionales de la guerra contra las drogas: dos estudios de caso de transformaciones de las comunidades políticas, 43 Ison., 151, 193, (2015). These authors have classified the "constitutional costs" that Mexico has endured in its "war on drugs" since 2006: a) The restriction on fundamental rights, b) The centralization of a federalist system, and c) The confusion about the faculties of different public institutions in the fight against organized crime. 
If we consider that criminal organisations in Mexico use ruthless war tactics to subject people, that they are merciless, that they have no respect for innocent people, it is opportune to ask the following question: Is it judicious in this context to be concerned with protecting scrupulously all constitutional rights of members of criminal organisations?

Unfortunately, the normative response of the $\mathrm{CNDH}$ and other Human Rights Organisations to this question, instead of solving the grave crises in these regions, impeded the timely design of constructive policies that could have helped the Mexican state to competently defend the basic rights of common people in front of organized crime.

All the same, this normative reply has rendered ineffective the Mexican state to neutralize conclusively organized crime. Moreover, this outlook has led many regions of this country to live in a permanent state of subjection to drug cartels, by which human rights of common people are trampled upon ruthlessly. Thus, the lack of acknowledgement of the crisis suffered in these regions is unfair for the millions of people who live there.

A formal declaration of emergency would be an acknowledgement of the true reality that this people endure. Conversely, the refusal to acknowledge this fact would expand severe consequences against these people.

On the other hand, the Mexican Law has not advanced adequate criteria to esteem, in a context of absence of the state, the fairness of self-defense against ruthless crime. Consequently, this lack of fair criteria emboldens more and more criminal organisations, because they feel over protected, whereas ordinary people feel increasingly desperate on the grounds that they perceive that the Mexican state has leaned more to the side of criminals than to their side.

Furthermore, the distress lived through in Guerrero and Michoacán resulted in the revival of indigenous customary law, since people needed to recover their ancestral traditions and customs to conquer organized crime and achieve their own development.

Based on the two main cases studied in this research, we infered that, through a robust human development and the efficient encouragement of social capital, people in Mexico could be able to efficaciously fight criminal organisations throughout the country.

Finally, the suspension of constitutional guarantees and the enactment of emergency laws are part of the portfolio of powerful instruments to reconstruct the peace, order, security and respect of human rights in the Mexican state. Nonetheless, to produce the expected result, they need to be accompanied by upright policies that shall redesign, for ordinary times, the law enforcement, the prosecutorial and the judicial systems, so that they guarantee the appropriate punishment and reparation of criminal actions, as well as the control mechanisms (judicial, assets, anti-corruption and social) ${ }^{106}$ of the authorities and society to prevent the growth of organized crime in Mexico.

106 See Edgardo Buscaglia, Vacíos de poder en México. Cómo combatir la delincuenCIA ORGanizada 28, 29 (Random House Mondadori 2013). 